\title{
'Bebaxšid' (Excuse Me) as a Multifunctional Speech Act in Persian
}

\author{
Massoume Khodaei Moghaddam \\ Ferdowsi University of Mashhad, Iran \\ Mahmoud Elyasi \\ Ferdowsi University of Mashhad, Iran \\ Shahla Sharifi \\ Ferdowsi University of Mashhad, Iran
}

\begin{abstract}
This study, based on the modified version of Brown and Levinson's model of Theory of Politeness (1987), examines and analyzes 'bebaxšid' (Excuse me) speech act in Persian language to come up with the functions it serves in the Iranian Persian-speaking community for those non-Persian speakers who want to speak or learn Persian. For this purpose, some native speakers of Persian language from different ages and different social groups were observed in such natural settings as markets, shops, the streets, and parties and their speech was recorded; then transcribed and translated into English; finally, the data was analyzed qualitatively. The results show that, there are ten major functions of 'bebaxšid' in Persian which are as follows: apologizing, phatic communication, as a kind of address term, mitigating request, giving a present or offering services, thanking, turn-taking, complaint, refusal, and asking questions. Finally, it is worth noting that using such politeness expressions as 'bebaxšid', are not just for mitigating face threatening act (FTA) and many speakers use them in different contexts to have a more polite and successful interaction and communication. This would be incompatible with general characteristics of politeness strategies defined and described by Brown and Levinson (1987) who consider politeness simply as a means of mitigating FTA.
\end{abstract}

Index Terms - bebaxšid, speech act, politeness, face, face threatening act, function

\section{INTRODUCTION}

Pragmatics is" the study of how more gets communicated than is said" (Yule, 2000, p.3),. Pragmatics is something more than what is said and in fact it studies the intention of the speakers. Regarding pragmatic competence as its basic component and, in turn, speech act, has been given particular attention as the most fundamental part within pragmatics (Schmidt \& Richards, 1980). Speech act theory was first introduced by Oxford philosopher J. L. Austin in How to Do Things with Words, published in 1962. A speech act, according to Austin (1962) is "the issuance of an utterance which is intended to accomplish or perform a specific act” (p. 6). So, speech act theory is concerned with uses of language. The main contribution of speech act theory is the explanation of communicative competence.

Speech acts, with different functions, are considered as a crucial element in everyday conversation, (Chen and Chen, 2007), so it is quite essential to investigate different types of them and their functions in order to have an efficient communication. 'Bebaxšid' (Excuse me) is one of these speech acts which has different functions and different meanings in different contexts in Persian. In order to use this speech act and react to it appropriately, and to avoid any communication failure, a Persian learner should be familiar with its different functions.

Although the study of speech acts has a rather long history (beginning in the 1960s), the study of production and perception of different speech acts related to Persian language has been started during the last 15 years. There are lots of studies carried out on speech acts realization. These studies mainly involve such speech acts as thanking (Koutlaki, 2002), complaint (Eslami-Rasekh, 2004), apology (Afghari \& Kaviani, 2005), gripping (Allami, 2006), invitation (Salmani-Nodoushan, 2006), compliment (Sharifian, 2008), disagreement (Parvaresh \& Eslami-Rasekh, 2009), condolence (Samavarchi, Allami, \& Samavarchi, 2009), suggestion (Pishghadam and Sharafadini, 2011), Insha' Allah (God's willing) and its functions in Persian (Pishghadam and Kermanshahi, 2012), but so far, there has been no study conducted in Persian to investigate different functions of 'bebaxšid' speech act. Hence, in this paper, we are to examine different functions involved with this high-frequent speech act in Persian.

\section{THEORETICAL FRAMEWORK}

Researchers working on pragmatics have carried out their studies based on different theoretical frameworks. One of these theories which has received much attention and has a crucial role in total comprehension of such speech act as 'bebaxšid' is Brown and Levinson's Politeness Theory (1978/1987). However, before dealing with politeness theory, it is quite essential to refer to Goffman's (1967) term of face work, which refers to a mechanism that is responsible for 
people's action being consistent with face. All people are expected to keep face of others during interaction (cited in Coppock, 2005). Later in 1987, Brown and Levinson expanded their theory as Politeness Theory. According to Brown and Levinson (1987) face is defined as "self public image", and has two aspects: negative and positive (p. 61); Negative face is "the wants of every competent adult member that his action be unimpeded by others", and positive face is "the wants of every member that his wants be desirable to at least some others" (p. 62). Scollon and Scollon (2011) define face as a "negotiated public image, mutually granted each other by participants in a communicative event" (p. 65).

Politeness is seen in terms of sets of strategies on the part of discourse participants for mitigating speech acts which are potentially threatening their own face or that of an interlocutor (Hickey and Orta: 1994, 267).

Another important notion related to the comprehension of 'bebaxšid' is that of indirect speech acts. According to Yule (2000) based on the structure, we have two types of speech acts: direct and indirect (p. 54), "Whenever there is a direct relationship between a structure and a function we have a direct speech act, and whenever there is an indirect relationship between a structure and a function we have indirect speech act" (p. 55).

Stapleton (2004) is of the opinion that indirect speech acts (ISAs) convey not only the literal meaning of the utterance, but also "the intended force in the speech act" (p. 17). It is worth mentioning that ISAs do not directly express what the speaker means and when s/he applies an indirect speech act, what s/he means may "deviate from what is literally said" (Woods, 2006: xii). There are different types of indirect speech acts (Cohen, 1996) which are preferred in social interaction, since they are considered as more polite. In Persian, 'bebaxšid' is an indirect speech act which plays different roles indicating different meanings in different contexts.

\section{METHODOLOGY}

This study has carried out with some native speakers of Persian language. More than 60 individuals (male and female) from different ages and different social classes were observed in such natural settings as markets, shops, greeting, on the street, in parties, etc. The process of data collection continued until it reached saturation point; it means that until no new function was found; then some instances were selected to be analyzed.

The process of data collection took around 4 months. Some part of this data was recorded and then transcribed and translated into English. On occasion, the researchers had to memorize some part of the data (because there was no access to a recording device at that time or being occasional of the data) and later to transcribe it, so that it might, at last, be analyzed qualitatively.

\section{PuRPose OF THE STUdY}

Since politeness is considered as a fundamental element in a communication, speakers try to make use of those words and expressions which are crucial to the success of an interaction; 'bebaxšid' is a speech act which is considered as polite expression in Persian, which plays different functions in different contexts. Persian speakers intuitively perceive its functions in all contexts, but this issue is difficult for most non-native speakers who are learning Persian and not being familiar with different functions of 'bebaxšid' may cause misunderstanding and miscommunication; so, we decided to deeply analyze it in order to come up with its various functions.

\section{RESULTS}

From the data gathered in different natural settings, ten major functions of 'bebaxšid' were observed in Persian language. Below, an example is given for each function of 'bebaxšid', which is followed by the translation of the utterance. The functions are as follows:

1- Apologizing

Context:

B (A's son) arrives home late and A (B's mother), is worried about him

A: čerâ inqadr dir kardi? negarân šodam.

B: bebaxšid xeili terâfik bud.

Translation:

A: Why are you so late? I was worried.

B: Excuse me; I was stuck in a traffic jam.

According to the family norms, B should come back home at the exact time and as he has violated this norm and has caused worry, he uses 'bebaxšid' to excuse his mother for being so late. Using 'bebaxšid' for apologizing is so common among Persian speakers.

2- Phatic Communication

Context:

At the Dentist's: A (Patient) and B (Secretary)

A: bebaxšid sâ?at do nobat dâštam.

B: bale befarmâyid bešinid.

Translation:

A: Excuse me; I've got an appointment at 2 o'clock. 
B: Yes, please take a seat.

In this context, A makes use of 'bebaxšid' to start the conversation and it does not indicate making an apology, whatsoever. In fact, using 'bebaxšid' in a formal situation is a polite and common expression to begin the conversation with in Persian language.

3- As a Kind of Address Term

Context:

$\mathrm{A}$ and $\mathrm{B}$ are in the library; they do not know each other. A wants to ask B a question.

A: bebaxšid

B: (B does not hear and does not answer)

A: bebaxšid

B: bale?

Translation:

A: Excuse me?

B: (B does not hear and does not answer)

A: Excuse me?

B: Yes?

In this context, A does not know B and wants to ask him a question, so he uses this expression to attract B's attention and addresses him with 'bebaxšid'. The expression in this context has a bit the concept of apology and mostly functions as an address term.

4- Mitigating Request

Context:

A and B (two friends). A is going to buy the book their teacher has recommended to the students for the course.

B: bebaxšid to ke dâri miri barâ manam bexar.

A: bâše, eškâli nadâre.

Translation:

B: Excuse me, if you are going to buy the book, buy one for me, too.

A: OK, no problem.

In this context, B asks A to do something that is not her duty, and this request may put A under pressure to do the job, so B by using 'bebaxšid' which indicates apology, to some extent, mitigates her request.

5- To Give a Present or to Offer Services

Context:

A has bought a present for B (her friend)'s birthday.

A: bebaxšid dige nâqâbele.

B: xeili mamnun.

Translation:

A: Excuse me, it is not worth mentioning.

B: Thanks so much.

In this context, A by using 'bebaxšid' along with 'nâqâbele', undervalues his present; otherwise it means that his present is not that much valuable for the recipient.

6- Refusal

Context:

A and B (two classmates) have an exam the next day.

A: miše jozvehâto bedi zire matâlebe mohem xat bekešam.

B: bebaxšid xodam hanuz hiči naxundam.

Translation:

A: May I have your notes to highlight the important points.

B: Excuse me, I haven't studied them yet (I need them).

In this context, B does not refuse his friend's request directly. He uses 'bebaxšid' to excuse him and refuse his request indirectly, since it is a polite way of refusing other people's request. A intuitively understands that in this context, this expression indicates both apology and refusal.

7- Thanking

Context: A had asked B (her father) to buy some books for her.

B: biyâ doxtaram inam ketâbâyi ke gofte budi.

A: bebaxšid bâbâ zahmat oftâdi.

Translation:

B: Here you are; this is the book you have asked me to buy for you.

A: Excuse me dad; you ran into trouble.

In this context, A knows that she has got her father into trouble, so she uses this expression to excuse him and to show that she cares deeply about this matter and to thank him.

8- Turn-taking 
Context:

A (Student) and B (A's teacher) are speaking about something. B is speaking at the moment.

A: bebaxšid vasate harfetunam hast vali be nazare man ...

Translation:

A: Sorry to interrupt, but in my opinion ...

In this context, A uses 'bebaxšid' to take turns; B is aware of this function and gives the turn to the other to speak.

9- Complaint

Context:

Some people are standing at the baker's in the line. A (Customer) arrives and does not join the line and directly goes to the baker's. B (another customer) who is waiting for a long time starts complaining.

B: bebaxšid âxare saf unvare.

Translation:

Excuse me, we're standing in the line!

In this context, A does not consider the other people's right, and so B by using 'bebaxšid' complains about his behavior. Here, this expression does not indicate an apology; rather, it means objection and complaint.

10- Asking to Repeat the Question

Context:

A (Professor) asks B (Student) to give a lecture next session.

A: xânume B lotfan barâ jalase ba?d âmâdeye ?erâ?eye dars bâšin.

B: bebaxšid?

Translation:

A: Miss B please be ready to present the lecture for the next session .

B: Excuse me?

In this context, B has not heard or has not understood A's utterance, so by using 'bebaxšid', wants B to repeat or explain his utterance.

\section{DISCUSSION}

This study was conducted to examine various functions of 'bebaxšid', which is one of the most frequent and useful politeness expressions in Persian. Considering function 1, it should be said that as people's face may be threatened in daily interaction and people may (un-)intentionally threaten each other's face, apologizing is a speech act which decreases this threat. That is why, the use of apology in social interaction is so widespread; for this reason, Brook (1999) calls our time, "the Age of Apology" (p.3).In fact when apologies are employed, "the speaker admits that a social norm was violated and that s/he was to somewhat part of its cause" (Marquez-Reiter, 2000, p. 57). According to Cross Cultural Speech Act Realization Patterns (CCSARP) project initiated in 1982 (see Blum-Kulka et al., 1989),The linguistic realization of the act of apologizing can take in the form of five possible strategies: an expression of apology, an acknowledgement of responsibility, an explanation or account of situation, an offer of repair and, a promise of future forbearance. 'Bebaxšid' in Persian is settled in the first formula; in other words, it is an expression of apology that is the most direct type of apologizing and according to Afghari (2007), and Shariati and Chamani (2009), this expression is the most frequent performative verb for apologizing in Persian. So, whenever Iranian Persian speakers feel that they have done something wrong or something not in accordance with other people's dignity, that may threaten their face, they use 'bebakhshid' to make an apology as a face saving speech act.

The second function of 'bebaxšid is phatic communication. According to Bronsislaw Malinowski (1884-1942), such sentences as "What a nice day", "Hello", "Good morning", are produced automatically and do not communicate any message, and thus are considered as stereotyped structures. This social role of language maintaining intimacy and friendship between people is called phatic communication (cited in Crystal, 2010, 10). 'Bebaxšid' in Persian, in some contexts, plays the same role, i.e. as an expression of phatic communication. It is specially used in formal settings where the speakers are unfamiliar to each other and are expected to make polite communication.

The other function of 'bebaxšid' is for "addressing strange people". When the speaker is in doubt as to how address strange people, s/he can use any term and instead s/he may use attention getters such as 'bebaxšid' to capture the attention of the addressee. Aliakbari and Toni (2008) call such attention getters as "zero address term".

Another function of 'bebaxšid' is for mitigating a request. As request may put pressure on others to do something and thus threaten their face, using some mitigating devices are necessary to decrease this threat. According to Brown and Levinson (1987) "by apologizing for doing an FTA, the speaker can indicate his reluctance to impinge on H's negative face and thereby partially redress that impingement" (p.187). Furthermore, using this expression before offering a request is interpreted as humility and politeness, and if the speakers do not employ this expression or any other kind of mitigating device, it is interpreted as something impolite.

'Bebaxšid' is also used when somebody gives a present or offers services to others; this is so common among Persian speakers and is often accompanied by other formulaic expressions as "qâbel nadâre" which may undervalue what is being given or offered. In fact, 'bebax̌̌id', in this context, may be interpreted as "shekastenafsi" (humility) or "ta'arof" (compliment) which are considered as two crucial features of Iranian culture. 
The other function of 'bebaxšid' is thanking. Thanking in Persian is the manifestation of politeness and is expressed through verbal and non-verbal devices. According to Cheng (2005), apologizing is one of the ways for thanking; 'bebaxšid' displays the same function in Persian in some contexts. It means that Persian speakers use this expression, when they feel extremely grateful and have received a favor that they have asked for. In fact, by using this expression, the speakers show their awareness of the trouble into which another person may have fallen by doing the favor. It is also used to show the awareness that the other person is not obliged to do the favor; in other words, they use 'bebaxšid' to express their thanking. Koutlaki (forthcoming) refers to such expressions as "apologies functioning as expressions of thanks".

The next function of 'bebaxšid' is turn-taking. According to Yule (2000), whenever in speaking the control on turn is not fixed, anyone can attempt to take it, that is called turn-taking (p.72). In Persian language, especially while speaking to a high status person, turn-taking is not allowed, but sometimes it is inevitable and the speakers use 'bebaxšid' to have a polite conversation.

Another function of 'bebaxšid' is refusal. Refusal is a high-risk face threatening act, because it contradicts the expectations. It is often realized through indirect strategies, and therefore, unlike acceptance, it requires a high level of pragmatic competence (Cohen, 1996). According to Beebe et al. (1990) using excuse is an indirect strategy for refusing other people's request, invitation and suggestion. 'Bebaxšid' has such a function in Persian. In other words, using 'bebaxšid' in some contexts is for refusing other people's request, invitation, etc., indirectly. Persian speakers care about others, their needs and wants, and they also know that they should not refuse other people's request directly as it is considered as a face threatening act. In such occasions, they prefer to use 'bebaxšid' to show apology and refusal.

Yet another function of 'bebaxšid' is its questioning function accompanied by a questioning tone and a questioning gesture. This expression, if produced with a questioning tone, is a formal and polite device for questioning. It is used when one has not heard or has not understood the other speech and by using this expression asks the addressee to repeat the utterance or explain the issue.

And finally, the last function of 'bebaxšid' is showing complaint or blame, which is considered as a face threatening acts. Sometimes, in daily interactions, making a complaint about something or blaming others is inevitable, and stating them through such expressions as, 'bebaxšid' decreases the threatening pressure.

In summary, the first function of 'bebaxšid' is used when a face threatening act has just happened and as mentioned before, it is considered as "face saving". The functions listed under numbers 4, 6, 8, and 9 are used before doing an FTA in order to decrease negative face threatening act, and are therefore considered as negative politeness strategies. The other functions are employed to maintain and enhance the addressees' face by being grateful to them.

Finally, it is worth noting that using such politeness expressions as 'bebaxšid', are not just for mitigating face threatening act (FTA) and many speakers use them in different contexts to have a more polite and successful interaction and communication. This would be incompatible with general characteristics of politeness strategies defined and described by Brown and Levinson (1987) who consider politeness simply as a means of mitigating FTA.

\section{REFERENCES}

[1] Aliakbari, M. \& Toni, A. (2008). The Realization of Address Terms in Modern Persian in Iran: A Sociolinguistic Study. Retrieved on Jan $18^{\text {th }}, 2013$ from linguistic-online.de/35-08/aliakbari.html.

[2] Afghari, A. (2007). A sociopragmatic study of apology speech act realization patterns in Persian. Speech Communication, 49, 177-185.

[3] Afghari, A. \& Kaviani, V. (2005). Apology speech act realization patterns in Persian, IJAL, 8 (2), pp. 1-28.

[4] Austin, J. (1962). How to do things with words. Oxford: Clarendon Press.

[5] Allami, H. (2006). A sociopragmatic analysis of griping: The case of Iranian students, Journal of Linguistics, 1 (1), pp. 59-76.

[6] Beebe, L., Takahashi, T., Uliss-Weltz, R., (1990). Pragmatic transfer in ESL refusals. In: Scarcella, R., Anderson, E., Krashen, S. (Eds.), Developing communication competence in a second language. New York: Newbury House, pp. 55-73.

[7] Brooks, R. L. (1999). The age of apology. In: R. L. Brooks (Ed.). When sorry isn't enough: The controversy over apologies and reparation for human injustice. (pp. 3-12) New York: New York University Press.

[8] Brown, P. \& Levinson, S. (1987). Politeness: Some universals in language usage. Cambridge: Cambridge University Press.

[9] Chen, S. \& Chen, S. E. (2007). Interlanguage requests: A cross-cultural study of English and Chinese. Journal of Linguistics, 2 (2), pp. 33-52.

[10] Cheng, S. W. (2005). An exploratory cross-sectional study of interlanguage pragmatic development of expressions of gratitude by Chinese learners of English. Unpublished PhD Dissertation; The University of Iowa.

[11] Cohen, A. D. (1996). Speech acts. (pp. 383-420). In S. L. McKay \& H. N. (1987). Sociolinguistics and language teaching, Hornberger (Eds.). New York: Cambridge University Press.

[12] Coppock, L. (2005). Politeness strategies in conversation closing. Retrieved on Apr $18^{\text {th }}, 2013$ from http://www.standford.edu/ coppock/face.pdf.

[13] Crystal, D. (2010). The Cambridge encyclopedia of language. New York: Cambridge University Press.

[14] Eslami Rasekh,Z. (2004). Face-keeping strategies in reaction to complaints: English and Persian, Journal of Asian Pacific Communication, 14(1),pp.179-195

[15] Hicky,L. \& Vazqueze Orta,l. (1994). Politeness as deference: A pragmatic view. Retrieved on May $4^{\text {th }}, 2013$ from http://www.rodin.uca.es:8081/xmlui/.../1/18228392.pdf.

[16] Koutlaki, S. (Forthcoming). A model of cultural analysis and its applications in the teaching of culture, In: The handbook of current research on teaching English language skills. Shahid Beheshti University Press. 
[17] Koutlaki, S. (2002). Offers and expressions of thanks as face enhancing acts: Tæ'arof in Persian, Journal of Pragmatics, 34 (12), pp. 1733-1756.

[18] Martinez-Flor, A. \& Uso-Juan, E. (2006). Pragmatic development in a second or foreign language: Some classroom techniques. Greta, pp. 50-56.

[19] Parvaresh, V. \& Eslami Rasekh, A. (2009). Speech act disagreement among young women in Iran. Comparative Literature and Culture, 11 (4), pp. 2-8.

[20] Pishghadam, R. \& Sharafadini, M. (2011). Delving into speech act of suggestion: A case of Iranian EFL learners. International Journal of Business and Social Science, 2 (16), pp. 152-160.

[21] Pishghadam, R. \& Norouz Kermanshahi, P. (2012) Insha'Allah (God's Willing) and its functions in Persian. Studies in Literature and Language. 4 (1), pp.1-6.

[22] Salmani-Nodoushan, M. A. (2006). A comparative sociopragmatic study of ostensible invitation in English and Farsi, Speech Communication, 48 (8), 903-912

[23] Samavarchi, L. \& Allami, H. \& Samavarchi, H. (2009) A contrastive study of the speech act of Giving condolences in English and Persian [abstract], Asian EFL Journal, 5, 34-78.

[24] Schmidt, R. W. \& Richards, J. C. (1980). Speech acts and second language learning. Applied Linguistics, 1 (2), pp. 129-157.

[25] Scollon, R. \& Scollon. S. W. (2011). Interpersonal politeness and power. In Hua, Z. (2011). The language and intercultural communication reader. London and New York: Routledge.

[26] Shariati, M. \& Chamani, F. (2010) Apology strategies in Persian, Journal of Pragmatics, 42, pp. 1689-1699

[27] Stapleton, L. E. (2004). Variation in the performance of speech acts in peninsular Spanish: Apologies and requests. Unpublished Doctoral Dissertation, University of Louisiana, Mississippi.

[28] Yule, G. (2000). Pragmatics. Oxford: Oxford University Press.

[29] Woods, N. (2006). Describing discourse. London: Hodder Education.

Massoume Khodaei Moghaddam She was born in Quchan, Iran in 1982. She received her Bachelor's degree in Teaching English Language from Azad university of Mashhad (Mashhad, Khorasan Razavi Province, IRAN) in 2008, after that she continued her studies in linguistics in Ferdowsi university of Mashhad, and she took her M.A in linguistics in 2013.

She is currently an English teacher in one of the guidance schools of Mashhad. Her main research interest is in applied linguistic and cultural linguistic.

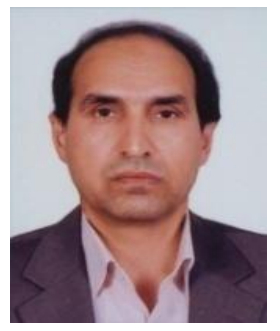

Mahmoud Elyasi He was born in Quchan, Iran in 1956. He received his B.A. degree in english language and literature from Ferdowsi University of Mashhad (Mashhad, Khorasan Razavi Province, IRAN) in 1983. Later in 1991, he got his MA degree in general linguistics from Ferdowsi University of Mashhad (IRAN). His thesis title was "A Study of 100 Linguistic Variables and Their Distribution in the Area Between Torbat-e Jam City and Mashhad City". He received his Ph.D Degree in general linguistics from University of Wales, Bangor (Bangor, Gwynedd, Wales, UK) in 2006. His doctoral thesis title was "Language Proficiency and Academic Achievement of Monolingual Persian-speaking and Bilingual Turkish-Persian-speaking School Children in Quchan".

He did his military service in the Iranian Navy from 1983 to 1985 . He worked as a SENIOR TRANSLATOR and EDITOR in Mashhad (Iran) for 7 years (1985-1992), and translated Theo van Els et al (1983) Applied Linguistics and the Learning and teaching of Foreign Languages into Persian, published in 1994. Later in September 1992, he started working as a UNIVERSITY INSTRUCTOR at English Language and Literature Department at Hakim Sabzevari University (formerly, Sabzevar Teacher Training University) (Sabsevar, Iran) where he taught some courses on Linguistics and Translation Theory. Having won a scholarship from Iranian Ministry of Science, Research and Technology to study at University of Wales, Bangor (UK), he received his PhD degree in General Linguistics in 2006, and continued to work at English Language and Literature Department at Hakim Sabzevari University as ASSISTANT PROFESSOR and translated Fromkin and Roman's (1988) An Introduction to Language into Persian, published in 2005. In September 2010, he moved to Ferdowsi University of Mashhad where he started working as ASSISTANT PROFESSOR at Linguistics Department. He has been working at the same department since then, teaching such courses as Sociolinguistics, Dialectology, A History of Persian Language, and Phonetics. Meantime, he supervised around $10 \mathrm{MA}$ theses in Linguistics, and published more than 10 articles, e.g. A Functional Description of the Narratives Produced by Kurdish-Persian Bilinguals, Asian Journal of Social Sciences \& Humanities, Vol 2, No 1, February 2013 (Japan); The Analysis of Language Change in the Kurdish Narratives Produced by 60 Kurdish-Persian Bilinguals, Asian Journal of Social Sciences \& Humanities, Vol 2, No 1, February 2013 (Japan); Foreign Accent Syndrome: Neurolinguistic: Description of a New Case, International Conference on Language, Literature and Linguistics (Dubai, UAE, December, 2011). His previous interests included Dialectology, and Phonetics, while now his interests are as follows: Bilngualism, Critical Discourse Analysis, and Pragmatics.

Dr Elyasi has been a member of Linguistic Society of Iran since 2010.

Shahla Sharifi is an associate professor of general linguistics in Ferdowsi University of Mashhad. She got her MA and Ph.D degree in general linguistics from the same University. Her main areas of interest are pragmatics, discourse analysis, typology and neurolinguistics. 